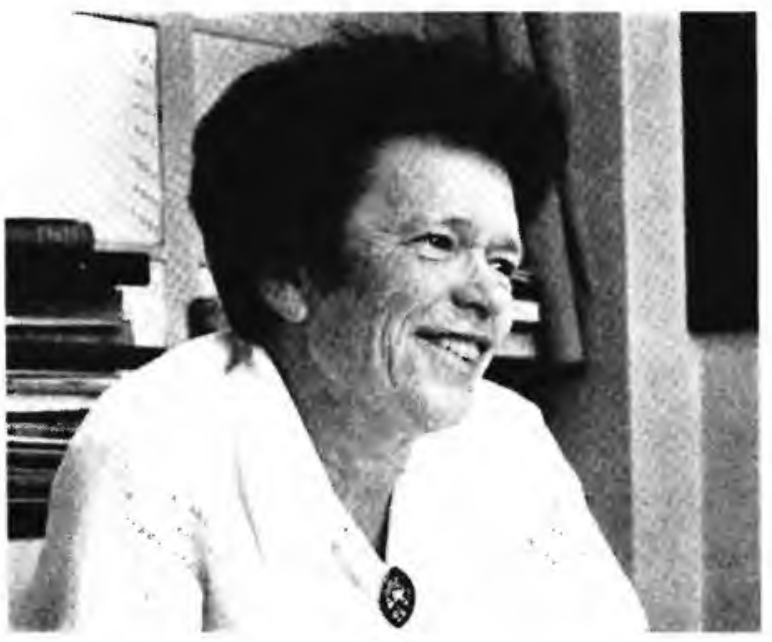

\section{Professor Jean Blair}

The Council of the University of the Witwatersrand, on recommendation of the Senate has granted Miss Jean Blait M.C.S.P. (dip.T.) the stallus of Associate Professor as from January Ist, 1973.

Miss Blair has been awarded this honour. in the words of the Vice Chancellor. "On the grounds of her long and meritorious service as a teacher on the staft of the University, having due regard to academic merit and other criterea"

Miss Blair has been on the staff of the University as Lecturer and later Senior Lecturer since 1946 and in 1969 was appointed Head of the Sub-department of Physiotherapy.

Besides holding this important position Miss Blair has sat on University committees and has been a member of the National Exccutive Committee of the S.A.S.P. since 1946. She was National Chairman of the S.A.S.P. from 1954-1969 and it was during this time that the Socicty and Profession took on the important role it now plays in the paramedical field.

\section{MERITORIOUS AWARD}

Miss Blair's influnce and forsight has played a kading part in the Jevelopment of the profession in thit country. and in the establishment of training of physio therapists.

Many physiotherapists, now practising and taiching in South Africi, and indeed. in many other corners of the globe. owe mucis to Miss Blair and her efforts on their behalf during their sludent days.

These persons, along with her own colleagues and contemporaries will take this opportunity. We fecl sure, of congratulating Professor Blatir on her very well deserved honour, as the first Prolessor in the field of rhysiotherapy in Sout Alrica. and will wish her conlinued success in the years ahead.

Not only is this award an honour to one of the lewing members of our Sociely but it is also a public recognition and honour for Physiothorapy in South Africa.

We congratulate you Professor Blatir! 


\title{
THE GRADUATE OF APPLIED SCIENCE
}

\author{
SHARON DANDY
}

\author{
Sharon Dandy graduated from the School of Physio- \\ therapy at the University of Toronto in 1965 and in \\ 1969 received her B.P.T. from the University of Mani- \\ toba, where she was a Gold Medalist. Since September, \\ 1969, she has been Clinical Supervisor at the Manitoba \\ Rehabilitation Hospital in Winnipeg. This paper is \\ derived from one she gave originally at the CPA \\ Annual Congress in Toronto, in June 1970.
}

The physiotherapist of today is at a cross-roads. We have been established for fifty years on this continent and during that time our image has grown and flourisined. We have improved and re-organised many spects of our total image. This represents progress and hievement of which we all are proud.

Nevertheless there is one flaw in this image which appears repeatedly. This flaw is both subtle and nebulous, insidiously biding its time, showing itself periodirally to remind us of its existence.

The flaw which is present in our total image can be best expressed by the words "The Technician" and "The Professional".

These two words, Technician and Professional, are very commonplace in our vocabulary. When one reads t.1rough the journal publications of the past ten years, these two words appear with uncanny regularity. In fact, in the past five years, the frequency of their occurrence has increased.

The following quotes are taken from articles which have appeared in our own Journal over the past five years. From the Professional Consultant's report to the Annual General Meeting, appearing in the September Journal, 1966:

"How can we strengthen our position on the medical team as one of a professional person rather than a technician?"

Also, from the President's address in the September 1968 issue:

"Is not the routine treatment of patients with little regard to sucin matters as assessing their needs, reevaluating treatment programmes, keeping of good records an indication of our willingness to be considered as technicians rather than respected members of a profession with skills based on scientific knowledge?"

This conflict between our professional and technical role is the flaw which is present in our image, and it is a potentially dangerous and serious flaw. If we really are professionals, why does the word technician cause us such concern? Why must we be reminded in articles that we are professionals and not technicians? Is it because we are, in reality, performing as technicians? Does not the total image of a physiotherapist include the visualisation of a technician? Yes, it does. A technician is defined as a person skilled and competent in the practical application of a science, or in the performance of a technique, or to be even more specific, in the performance of a physiotherapy technique.

However, our total image also includes the visualisation of a professional. A professional was originally defined as a member of a learned art or science. Presently the definition has come to include that individual who possesses a specialised body of knowledge within some branch of learning. The physiotherapist possesses a specialised body of knowledge and thus would be included in this definition.

Our image must therefore encompass both the professional and the tecinnician. If this is true, why do we experience such conflict between these roles? We are in conflict because we have failed to recognise our own identity. This conflict of roles is only a symptom of a more intrinsic problem. The problem is not to define whether we are professionals or technicians. We are both. What we must decide is which components of each are required to make a pinysiotherapist.

Consider the Engineer, and the Engineering profession. These people are graduates of science as applied to Engineering. The Engineer is a professional because he is a member of a learned science. He also possesses the talents of a technician because he is skilled and competent in the practical application of the learned sc.ence.

A physiotherapist is a graduate of a course in Applied Science, medical science as applied to physiotherapy. The two major sciences that form the basis for a physiotherapist's knowledge are Anatomy and Physiology. These two courses demand a large percentage of the total hours of training of a physiotherapist. They give us the knowledge and understanding required to perform. They in fact enable us to think, reason and solve the problems presented by each and every patient. They are the backbone of our training for, without them, our techniques are meaningless.

Anatomy, to the Anatomist, is a pure science science for its own sake; but to the physiotherapist, Anatomy is an applied science - science studied for a practical purpose. The physiotherapist could well be described as an Applied Anatomist, applying static and dynamic Anatomy to movement whether normal or abnormal. Similarly she is also an Applied Physiologist, applying this knowledge to exercise under normal and abnormal conditions.

But does the physiotherapist utilise this knowledge?

1. Do we remember our Anatomy and Physiology after graduation?

2. Do we find with each successive year that this knowledge becomes depleted?

3. Do we look at the patient and visualise the structures underlying the surface?

4. Do we observe a patient's gait and analyse it as moving Anatomy?

5. Do we in fact think in terms of Anatomy and Physiology when an exercise is performed?

If the answers are positive, then we are indeed graduates of applied science. If the answers are negative, this could well explain the uncertainties in our role as a professional and technician.

If the answers are negative, then we must ask ourselves why? Why is this knowledge not being retained? 
The answer would seem to be disuse, for it is only through disuse that knowledge is forgotten or discarded.

In discussing the problem-solving related to the 'professional" and "technician" roles, two steps emerged.

First: We recognised the problem - a flaw, which presented itself as a conflict between the roles of a professional and a technician.

Second: We defined the problem - the terms professional and technician were merely symptoms of an underlying problem. The problem itself was defined as a difficulty in applying science when performing physiotherapy.

Next, the third step is to solve the problem. We must learn to apply the science of Anatomy and Physiology to the problem presented.

The whole key to the flaw in our image may well be the inability to apply science, the science of Anatomy or Physiology, to the problems presented by the patient; or to be more exact, to apply science to the signs and symptoms which the patient presents.

Using the scientific approach in treating patients we must -

1. Recognise the problem: Perform a physical examination on the patient. Examine is a word that we avoid for it has been claimed that physiotherapists do not examine, they assess. By definition "assess" means to "fix, impose, estimate, or value," "Examine" is defined as "investigate, inquire into the nature or condition, ask question of, or test proficiency of." By definition, we examine and we assess. We are given a patient with a diagnosis. This immediately gives us information about the problem involved but we will require further knowledge regarding the actual structures involved and the degree of their involvement in order to plan the required treatment programme. Therefore we must inquire and investigate. We do in actual fact examine; but we also assess. We estimate, to establish a base line, and then we re-estimate and revalue to determine if the treatment programme is solving the problem. Therefore we assess the programme and its effect on the patient. Step one then is to recognise the problem, investigate, study, estimate, evaluate, determine which symptoms are being presented.

2. Define the problem: Assess and interpret the results of the examination. Correlate anatomical structures and physiological facts with the symptoms presented. Ask why and what? What specific structure is responsible for the defect? Is it muscular, ligamentous, bony? Why is it defective? Is it weak, spastic, shortened, scarred? The symptoms are only clues, they indicate the general area involved. To discover the actual site and cause of the disturbance, the physiotherapist must interpret or translate the symptoms into defined scientific facts: Having recognised the problem we must then define it.

3. Solve the problem, or problems, so defined: Each altered anatomical structure or physiological factor will represent a problem which may be solved by the application of one or more techniques. Thus. our technical skill is applied to an abnormal or defective structure, not to a diagnosis or to a symptom.

It is not sufficient merely to recognise. We must also define. The solution must be applied to the defined structures, not to the symptoms which are being pre- sented. It is only through a complete understanding a problem that a valid solution can be formulated. of physiotherapist will gain complete understanding $T^{\text {he }}$ defines a problem within the boundaries of her she knowledge, that knowledge being science as applied to
physiotherapy.

These three steps - recognition, definition and solu. tion - can be performed satisfactorily if the physio. therapist is both a professional and a technician. However, if the physiotherapist applies a technique to symptom, then she has decreased the number of steps involved to just two - recognition and solution. In this case, the physiotherapist is a technician. She has dis. carded the professional component. To define a proh. lem we must possess scientific knowledge. The physio. therapist who is capable of defining will retain her knowledge of Anatomy and Physiology, but the physio. therapist who does not define will forget these sciences through disuse.

If, following graduation, our scientific knowledge is forgotten and, at the same time, our manual skills performing techniques improve with practice, the en product will be a highly skilled technician or, to be more explicit, a skilled labourer.

The time has come when we must look critically at what we are, and what we profess to be. We claim to be responsible persons with high professional values and standards. We are seeking recognition, status, pres. tige, and a high salary for we claim that we deserve these rewards.

We have been given opportunities far exceeding many ohter individuals. We have a specialised training which has given us educated minds. If we use these minds we will gain the recognition and respect which we are seeking. But if we forget this knowledge then we are performing a serious injustice, and we are actually guilly of gross negligence.

At present there is a great deal of emphasis on education, both at the undergraduate and graduate levels. Degree programmes are being instituted at many universities across the country. This is very important if it is truly a quest for further knowledge, but it does seem slightly ironical to be up-grading education, when we are having difficulty retaining and utilising the knowledge obtained from our basic education.

It was stated earlier in this paper that Anatomy and Physiology consume a large number of the total hour of a physiotherapist's training. Nevertheless, the seems to be a large percentage of this knowledge that is lost following graduation. Although we do spend a great deal of time learning the medical sciences, there must still be a deficiency in the teaching process, or this knowledge would not be discarded.

Anatomy is the science that requires the most teaching hours and yet it is the subject matter which is very often forgotten.

The deficiency is not in the teaching of static or dead Anatomy but we are definitely deficient in acquiring the knowledge of dynamic, living Anatomy. We are well versed in Anatomy at rest, but we are quite ignorant of Anatomy in motion. If we consider that all the problems presented to us by the patients involve movement, this is a grave deficiency. The Anatomical position may be satisfactory for the Anatomist, but it is certainly not sufficient for the physiotherapist. How can the physiotherapist be expected to define adequately the patient's problems when she has not been equipped with a sufficient understanding of dynamic Anatomy?

It has been said by an Anatomist that the physiotherapist could become a specialist in the knowledge 
of the musculo-skeletal system. This is very true, but she certainly will not be if she is not equipped with ef aspect of its mechanisms, the major aspect being motion.

If we demand professional status, then we must be prepared to accept its responsibilities. If we are to be nembers of a learned science then we must be educated in these sciences. We must seriously question whether we are being educated to be professionals or to be only technicians.

physiotherapy is a very challenging and demanding vocation, composed of both scientific knowledge and ractical technique. This is a difficult balance to achieve without becoming over-weighted on either end. At preent our image seems to indicate that we are overweighted by practical technique. This imbalance reaires urgent attention because this vocation is at a ross-road in its development. There are two clearly defined avenues open. In one direction there lies a dead defined we carry on, leaving the imbalance unchanged, will quickly find that this vocation will stagnate. ot only will it grind to a halt, but other vocations, such as physical education, will quickly expand to take in many aspects of this field within its own realms of knowledge. Already the physical educator is becoming exceedingly well educated in the fields of applied physiology and applied anatomy.

The alternative is to accept the challenge. Establish the required balance between technique and the vital knowledge of the applied sciences. All members of this vocation - staff therapists, supervisors and educators - must recognise, define and solve.

Finally, the following three questions are put forward:

First - It has been stated that two of the primary functions of a university professional school are:

1. The transmission of that specialised body of knowledge that is the basis of performance;

2. The creation of new and better knowledge on which professional practise can be based.

Are we fulfilling these functions?

Secondly - Administrative and supervisory personnel are responsible for providing opportunities and stimulus for their staff which will enable the staff to desire and seek further development and advancement.

Are we fulfilling these responsibilities?

Thirdly - It is the duty of the physiotherapist to utilise and further increase the specialised knowledge of her vocation to provide the best possible standard of patient care.

Are we fulfilling this duty?

If the answer to these three questions are positive, then we have indeed chosen the correct path. "Professional" and "Technician" will become obsolete terms for us because we will truly be respected and recognised "Graduates of Science as applied to Physiotherapy".

(With acknow'ledgements to Caradian Physiotherapy Journal)

\section{BRANCH NEWS}

\section{SOUTHERN TRANSVAAL BRANCH}

Lectures

November: Film evening - "Growth and Development of Children". "Congenital Fragility of Bone".

January: Lecture on "Soft Tissue Injuries" by Miss Sutcliffe.

February: Film and short talks on "Cervical Syndrome".

\section{sst Graduate Course}

January 22, 23, 24, Miss Sutcliffe lecturing on:

1. Management of peripheral nerve and hand injuries.

2. Management of rheumatoid and osteo-arthritic patients.

3. Use of heat and cold therapy.

Soft tissue injuries and ultrasound techniques.

4. Handling of geriatric patients.

\section{Volunteers urgently required}

To help at Mandeville Sports Centre for Paraplegics. Please contact Mr. Wenham, 42-3469.

News of Members

Marion Main and Tessa Skinstad are both leaving

Baragwanath in February, as they are expecting babies.

We say goodbye to Sue Hind who flies off to Europe soon.

We are sorry to lose Gail Bell from the Transvaal when she transfers to Cape Town.

\section{New Members}

We welcome several new members this quarter: Miss Lenore Davids, Miss Harken, Miss Israel, Mirs. Gerdener (who transferred from Natal Coastal Branch), Mrs. B. Bloom, Miss M. Thing.

Miss Melodene Murphy is resigning from the office of Chairman of the Branch Executive Committee as from the end of January as she is to be married early in February. She then expects to be living in the Goldfields area.

The Branch would like to take this opportunity of wishing Mel and her fiancé all the very best on the occasion of their marriage, and to thank her for all the hard work she has put in for the Branch during her years in office and before when she was an Executive Committee member.

\section{NOORD TRANSVAAL-TAK}

\section{Lesings en Vergaderings}

Januarie: 'n Algemene Vergadering is gehou om die program van die volgende jaar te bespreek.

Februarie: 'n Baie interessante lesing is gegee deur dr. T. J. de Jager oor kongenitale deformiteite.

\section{Sosiaal}

'n Baie suksesvolle Braaivleis is by mev. Downer se huis gehou in November verlede jaar. Ons fondse is na dese ook heelwat versterk.

\section{Lede}

Geluk aan die 14 finale jaar studente van 1972 wat 'n $100 \%$ slaag syfer behaal het.

Welkom aan die volgende nuwe lede mejj. $H$. van $Z y l$, Y. Hickley, C. Eales, R. Fawell, C. Eksteen, S. Ferreira en mev. V. Cranke. Ook 'n welkom aan mej. M. Ferreira (S. Tvl.), mev. la Grange (W.P.) en mej. E. Kotze (Noord K.P.). 